\title{
PELATIHAN PENELITIAN TINDAKAN KELAS DAN PENULISAN KARYA TULIS ILMIAH SMA PERJUANGAN DEPOK
}

\author{
Abdul Karim ${ }^{1}$, Huri Suhendri ${ }^{2}$, Arfatin Nurrahmah ${ }^{3}$ \\ 1,2,3 Program Studi Pendidikan Matematika, Fakultas Matematika dan Ilmu Pengetahuan Alam \\ Universitas Indraprasta PGRI \\ Email: abdul.depok@gmail.com
}

\begin{abstract}
One of the requirements thatmust be met is to improve the quality of educa tion by creating professional teachers. Based on the results of observations made from 9 (nine) teachers, only 1 (one) teacher has the ability to compile CAR, while 8 (eight) people do not have the ability to compile CAR. This is due to the lackof teachers getting information about the technique of preparing the CAR and the teachers are not accustomed to compiling research, so that the teachers are less able to prepare CAR In this regard, it is necessary to make efforts to improve the abilityof teachers in preparing CAR. The purpose of this community service activity is to increase teacher professiona li sm through class room action research and writing of environmental scientific papers at SMA Perjuangan Terpadu. The method of activities carried out in this community service is training / counseling, guidance andmentoring which is integ rated in classroom action research workshops (PTK). The form of activities to be ca rried out is training in the form of: designing and implementing models, methods, media, and learning approaches as outlined in the classroom action research proposal; implementation of classroom action research; interpreting implementation results throughclassroom action research reports; and writing scientific papers. The outputs that will be produced in this activity include: classroom action research proposals, classroom action research reports, and journals published by the teacher. All participants will be accompanied and guided in the process of making proposals, reports, and copying articles in accredited ornot accredited national journals.
\end{abstract}

Keywords: Training, ClassroomAction Research, Scientific Writing

\begin{abstract}
Abstrak. Salah satu persyaratan yang harus dipenuhi untuk meningkatkan kualitas pendidikan den gan menciptakan guru yang professional. Berdasarkan hasilobservasiyang dilakukan dari 9 (sembilan) orang guru, hanya 1 (satu) orang gurumemiliki kemampuan menyusun PTK, sedangkan 8 (delapan) orang belum memiliki kemampuan menyusun PTK. Hal ini disebabkan kurangn ya guru men dapatkan informasi tentang teknik penyusunan PTK dan guru tidakterbiasa menyusun penelitian, sehingg a para guru kurang mampu dalam menyusun PTK. Berkaitan dengan haltersebut, makaperlu adan ya upaya untuk meningkatkan kemampuan guru dalam menyusun PTK. Tujuan dari kegiatan pengabdian kepada masyarakat ini ialah untukmeningkatkan profesionalitas guru melaluipenelitian tindakan kelas dan penulisan karyailmiahlingkungan SMA Perjuangan Terpadu. Metode kegiatan yang dilakukan pada pengabdian kepada masyarakat iniadalah pelatihan/penyuluhan, pembimbingan dan pendampingan yang terintegrasi dalam kegiatan workshoppenelitian tindakan kelas (PTK).Bentuk kegiatan yang a kan dilakukan yaitu pelatihan berupa: perancangan dan penerapan model, metode, media, maupun pendekatan pembelajaran yang dituangkan dalam proposal penelitian tindakan kelas; pelaksanaan penelitian tindakan kelas; menginterpretasikan hasil pelaksanaan melalui laporan penel itian tindakan kelas; dan penulisan karya ilmiah.Luaran yang akan dihasilkan pada kegiatan ini antaralain: proposal penelitian tindakan kelas, laporan penelitian tindakan kelas, danjurnalyang dipublikasikanole h guru. Seluruh pesertaakan didampingidan dibimbing dalam proses pembuatan proposal, laporan, hing ga mensumbitartikel padajurnal nasional yang terakreditasiatau tidak terakreditasi.
\end{abstract}

Kata kunci : Pelatihan, Penelitian Tindakan Kelas, Karya Tulis Imiah

\section{PENDAHULUAN}

Manusia merupakan makhluk yang bergelut secara intens dengan pendidikan. Itulah sebabnya manusia dijuluki animal educandum dan animal educandus yaitu makhluk yang mendidik dan makhluk yang didik. Dengan kata lain, manusia adalah makhluk yang senantiasa terlibat dalam proses pendidikan, baik yang dilakukan terhadap orang lain maupun terhadap dirinya sendiri. Pendidikan sebagai upaya manusia yang merupakan aspek dan hasil buday a terbaik yang mampu disediakan setiap generasi 
manusia untuk kepentingan generasi muda agar melanjutkan kehidupan dengan cara hidup mereka dalam konteks sosio-budaya. Pendidikan mampu berperan mengantisipasi dan mengatasi persoalan, oleh karena itu pendidikan memegang kedudukan dalam menanggapi tantangan masa depan.

Pentingnya sebuah pendidikan tidak terlepas dari peran guru yang profesional. Seorang guru dikatakan profesional apabila memiliki empat kompetensi yaitu kompetensi pedagogik, kompetensi kepribadian, kompetensi sosial, dan kompetensi profesional yang diperoleh melalui pendidikan profesi. Seluruh kompetensi tersebut diperlukan karena seoarang guru bertugas tidak hanya mentransfer ilmu pengetahuan namun juga mendidik dan membina karakter peserta didik. (Jana, 2018) mengatakan guru yang profesional sangat diperlukan oleh tiap satuan pendidikan, karena guru yang profesional merupakan faktor penentu proses pendidikan yang bermutu sehingga berperanpenting terhadap perubahan dan kemajuan suatu bangsa termasuk bangsa Indonesia. Salah satu cara untuk pengembangan profesi berupa penulisan karya tulis ilmiah. Penelitian Tindakan Kelas (PTK) dan laporannya merupakan salah satu satu bentuk karya tulis ilmiah. Laporan tersebut akan bermakna lagi jika nantinya dapat diformat menjadi artikel berbasis penelitian dan dipublikasikan melalui jurnal ilmiah. Artinya, PTK dan laporannya serta artikel dan publikasinya sebagai satu kesatuan sangat penting dilakukan oleh seorang guru. Jika guru mampu melakukan aktivitas tersebut sebagai bentuk aktualisasi diri dalam rangka menjalankan Tugas profesional dengan sebaik-baiknya, memiliki dampak yang luas seperti kenaikan golongan, sertifikasi dan lain-lainnya.

Menurut (Gazali et al., 2019) dan (Marlena et al., 2017) Kesulitan utama guru untuk naik pangkat khususnya IV/a ke IV/b adalah guru-guru tidak dapat membuat karya tulis ilmiah. Hal ini sesuai dengan Peraturan Menteri Negara Pendayagunaan Aparatur Negara dan Reformasi Birokrasi Nomor 16 Tahun 2009 tentang Jabatan Fungsional Guru dan Angka Kreditnya berupa pengembangan keprofesian berkelanjutan. Secara eksplisit diwujudkan melalui: (1) pengembangan diri, yakni: diklat fungsional; dan kegiatan kolektif guru yang meningkatkan kompetensi dan/atau keprofesian guru; (2) publikasi ilmiah, yakni: publikasi ilmiah atas hasil penelitian atau gagasan inovatif pada bidang pendidikan formal. Dalam aturan tersebut juga secara jelas dimuat, jika guru akan mengajukan kenaikan pangkat, karya ilmiah menjadi bagian dari persyaratan wajib dari unsur pengembangan profesi. Artinya, PTK bagi seorang guru menjadi sangat penting kedudukanya, baik sebagai pengembangan profesi secara internal maupun pengembangan karir yang bersangkutan di masa mendatang.

Berdasarkan hasil wawancara yang dilakukan dengan beberapa guru di lingkungan SMA Perjuangan Terpadu, diperoleh informasi bahwa pemahaman dan pengetahuan guru mengenai Penelitian Tindakan Kelas kurang dan guru masih kesulitan untuk membuat suatu karya ilmiah, khusunya karya ilmiah dari hasil penelitian. Hal ini sependapat dengan (Widayati et al., 2018) dari 9 (sembilan) orang guru, hanya 1 orang guru memiliki kemampuan menyusun PTK, sedangkan 8 orang belum memiliki kemampuan menyusun PTK. Padahal untuk persyaratan kenaikan pangkat, diwajibkan untuk membuat karya ilmiah yang diterbitkan dalam jurnal. Masalah lain yang dialami adalah para guru sebenarnya sadar secara tidak langsung ketika proses belajar mengajar terjadi, sudah melakukan sebuah penelitian tindakan kelas, namun karena minimnya pengetahuan guru mengenai PTK, sehingga guru tidak mampu melakukan sesuai dengan alur yang ada dalam PTK. Kondisi ini yang menarik perhatian dan minat tim abdimas untuk mencoba membantu para guru-guru di SMA Perjuangan Terpadu Depok dengan mengadakan pelatihan dalam bidang pengajaran dan penelitian, khususnya penelitian tindakan kelas dan penyusunan karya ilmiah. Kegiatan ini diharapkan dapat memberikan panduan secara operasional dan dapat membantu para guru untuk meningkatkan karir mereka di dunia kependidikan.

Adapun partisipasi mitra dalam hal ini adalah pihak SMA Perjuangan Terpadu Depok dalam kegiatan pengabdian kepada masyarakat antara lain: 1) Partisipasi dalam perencanaan dan 
pengambilan keputusan. Wujud partisipasi dalam pengambilan keputusan antara lain ikut menyumbangkan gagasan atau pemikiran dalam kegiatan observasi, kehadiran dalam rapat dan tanggapan terhadap program pengabdian yang ditawarkan. 2) Partisipasi dalam pelaksanaan, meliputi: penyediaan tempat, sumber daya dana, kegiatan administrasi, koordinasi dan penjabaran program. Partisipasi dalam pelaksanaan merupakan kelanjutan dalam rencana yang telah digagas sebelumnya baik yang berkaitan dengan perencanaan, pelaksanaan maupun tujuan. 3) Partisipasi dalam evaluasi. Partipasi dalam evaluasi ini berkaitan dengan pelaksanaan program yang sudah direncanakan sebelumnya. Partisipasi dalam evaluasi ini bertujuan untuk mengetahui ketercapaian program yang sudah direncanakan sebelumnya.

Beberapa pengabdi sebelumnya juga telah melaksanakan pengabdian mengenai pelatihan penulisan PTK, sehingga pelatihan PTK ini dianggap penting dan perlu untuk melatih guru dalam melakukan penelitian sebagai salah satu solusi mengatasi permasalahan yang ada di kelas tempat mengajar. Kegiatan pelatihan PTK juga sebagai upaya untuk melatih guru-guru terampil dalam membuat karya tulis ilmiah dilaksanakan untuk guru-guru dilingkungan SMA Perjungan terpadu berhasil memperlihatkan sikap antusias peserta didik sehingga kegiatan berjalan dengan baik serta menghsilkan produk proposal PTK dengan judul yang beragam kondisi ini mencerminkan keberhasilan pelatihan dengan baik (Wiganda, 2014). PTK sendiri mampu meningkatan pengetahuan yang signifikan mengenai pemahaman terhadap penelitian tindakan kelas, pengolahan dan analisis data (Sunendiari et al., 2014), memperkuat wawasan guru tentang pokok-pokok pikiran yang harus dibuat dalam latar belakang penelitian PTK (Jayanta et al., 2017). Perbedaan pelatihan PTK yang telah dilakukan pengabdi terdahulu adalah pada inovasi pendampingannya. Pelatihan PTK ini selain disampaikan materi dan teknis pelaksanaan juga ada pendampingan intensif dari mulai penyusunan proposal, pendampingan pelaksanaan terakhir pembiatan laporan. Sehingga kegiatan pengabdian ini total dalam pendampingan sampai tuntas pada laporan.

\section{METODE PELAKSANAAN}

Waktu pelaksanaan kegiatan selama bulan Maret hingga Agustus tahun 2020, kegiatan pelatihan dilaksanakan selama 6 bulan. Kegiatan pelatihan ini akan dilaksanakan di SMA Perjuangan Terpadu Depok, yang beralamat di Jalan Raya Sawangan No. 1, Pancoran Mas, Depok, Jawa Barat. Pada kegiatan pengabdian kepada masyarakat ini, metode yang digunakan adalah pelatihan, pembimbingan serta melakukan pendampingan yang diintegrasikan melalui kegiatan pelatihan penelitian tindakan kelas dan penyusunan karya tulis ilmiah. Metode yang digunakan untuk mencapai tujuan yang telah dirumuskan di atas. Materi yang diberikan saat pelatihan memuat pengenalan, perancangan dan penerapan.

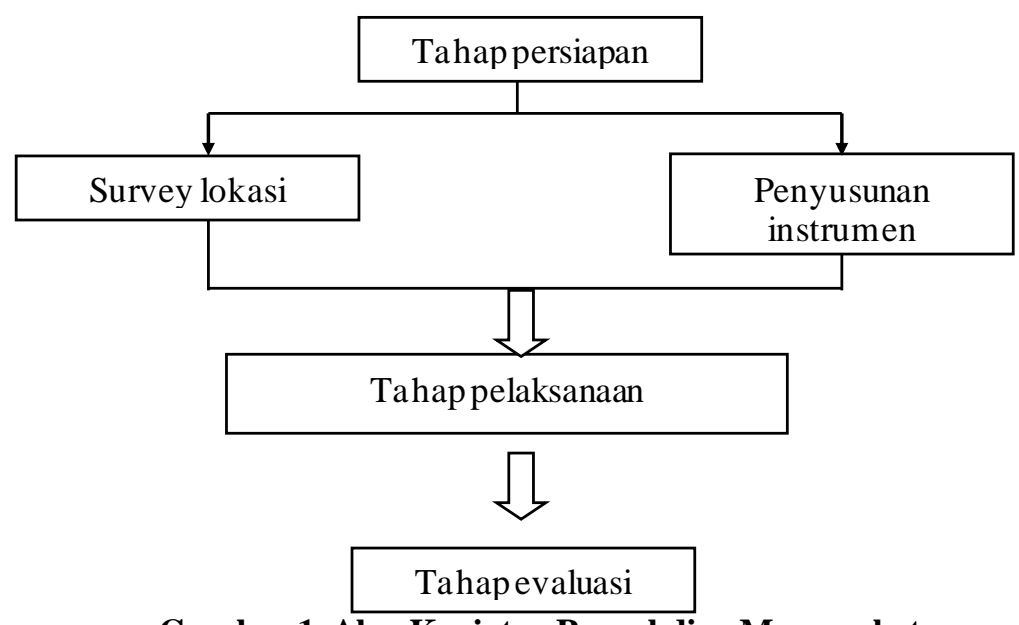

Gambar 1. Alur Kegiatan Pengabdian Masyarakat 
Pelaksanaan kegiatan ini dilakukan dalam tiga tahap, yaitu tahap persiapan, pelaksanaan, dan evaluasi, yaitu:

1) Tahap pertama adalah tahap persiapan. Dalam tahap ini tim melakukan survei pendahuluan untuk mengetahui kondisi target kegiatan dengan menganalisis kondisi tempat yang akan digunakan, kondisi peserta yang akan diberikan pelatihan, dan menyusun rancangan kegiatan yang akan dilakukan;

2) Tahap kedua yaitu tahap pelaksanaan. Tim melakukan pelatihan berupa pemberian informasi mengenai pentingnya seorang guru menguasai teknologi informasi dan komunikasi, yang ditujukan untuk seluruh guru di lingkungan SMA Perjuangan Terpadu;

3) Tahap ketiga adalah monitoring dan evaluasi. Evaluasi kegiatan ini dilakukan terhadap proses kegiatan. Evaluasi berkaitan selama kegiatan berlangsung dari tahap persiapan sampai tahap pelaksanaan, yang meliputi keadaan sekolah, kehadiran peserta pelatihan, antusias peserta saat mengikuti kegiatan, dan saran atau kritik terhadap kegiatan. Tahap monitoring dan evaluasi. Pada tahap ini, tim memonitoring pelaksanaan penelitian tindakan kelas yang dilakukan oleh guru. Monitoring dilakukan di akhir siklus I dan siklus II untuk mengevaluasi tindakan apa yang akan diterapkan selanjutnya. Siklus akan berhenti jika target yang diinginkan oleh guru sudah tercapai atau terpenuhi. Monitoring juga akan dilakukan dalam proses publikasi artikel hasil laporan penelitian tindakan kelas ke dalam jurnal. Guru akan dibimbing mulai dari pembuatan laporan hingga penulisan artikel. Proses monitoring dilakukan secara online melalui whatssapp.

\section{HASIL DAN PEMBAHASAN}

Sesuai dengan skema yang sudah direncanakan oleh tim abdimas, pelaksanaan kegiatan ini dilakukan dalam tiga tahap, yaitu tahap persiapan, pelaksanaan, dan evaluasi. Realisasi pelaksanaan sesuai dengan perencanaan tim pelaksana. Pada tahap evaluasi dan monitong, terkendala oleh situasi karena guru tidak lagi melakukan pembelajaran di kelas, namun melakukan Pembelajaran Jarak Jauh (daring). Pada tahap persiapan, tim pelaksana berkomunikasi dengan Kepala SMA bernama Edi Triyono, M.Pd melalui Whatsapp. Dari hasil diskusi tersebut, didapatkan bahwa permasalahan yang dihadapi guru adalah: 1) pemahaman dan pengetahuan guru mengenai Penelitian Tindakan Kelas kurang dan guru masih kesulitan untuk membuat suatu karya ilmiah, khususnya karya ilmiah dari hasil penelitian; 2) Masalah lain yang dialami adalah para guru sebenarnya sadar secara tidak langsung ketika proses belajar mengajar terjadi, sudah melakukan sebuah penelitian tindakan kelas, namun karena minimnya pengetahuan guru mengenai PTK, sehingga guru tidak mampu melakukan sesuai dengan alur yang ada dalam PTK.

Berdasarkan masalah tersebut, tim pengabdian dan pihak SMA Perjuangan Terpadu sepakat mengadakan kegiatan pengabdian masyarakat untuk meningkatkan kompetensi guru melalui pelatihan yang bertujuan memberikan gambaran yang lebih jelas dan juga fungsi evaluasi proses pembelajaran, artinya guru dapat berinteraksi dan terlibat langsung dalam proses pembelajaran. Interaksi langsung tersebut tentunya akan menghasilkan analisis yang lebih obyektif tentang keadaan kelas sebenarnya, sehingga guru dapat menentukan sikap dan tindakan yang tepat terhadap masalah yang muncul dalam proses pembelajaran. Berdasarkan kesepakatan bersama pula, kegiatan pelatihan tidak hanya untuk guru-guru di SMA Perjuangan Terpadu, namun juga untuk guru-guru SD dan SMP Perjuangan Terpadu.

Adapun pelatihan yang diberikan meliputi materi: PTK sebagai Pengembangan Profesi Guru dan Langkah-langkah Menyusun PTK. Sesuai dengan kesepakatan yang dilakukan antara tim abdimas dan pihak SMA Perjuangan Terpadu, maka pelaksanaan kegiatan abdimas akan dilakukan Hari Jumat, tanggal 6 Maret 2020. Pada hari Jumat, 6 Maret 2020, tim berkumpul di lokasi pengabdian pukul 12.00. Setelah solat jumat, tim menuju aula tempat kegiatan akan dilaksanakan. Peserta melakukan registrasi, dan tepat pukul 13.00 kegiatan dimulai 
dengan pemberian sambutan yang disampaikan oleh Kepala SMA Perjuangan Terpadu yaitu Bapak Edi Triyono, M.Pd, dilanjutkan dengan sambutan dari perwakilan tim pengabdian yang disampaikan oleh Bapak Fauzi Mulyatna, M.Pd. Pada pukul 13.15 kegiatan dilanjutkan dengan penyampaian materi mengenai PTK sebagai Pengembangan Profesi Guru yang disampaikan oleh Bapak Yogi Wiratomo, M.Pd. Pada materi mengenai PTK sebagai Pengembangan Profesi Guru, disampaikan bahwa Penelitian Tindakan

Gambar 1. Penyampaian Materi PTK sebagai Pengembangan Profesi Guru

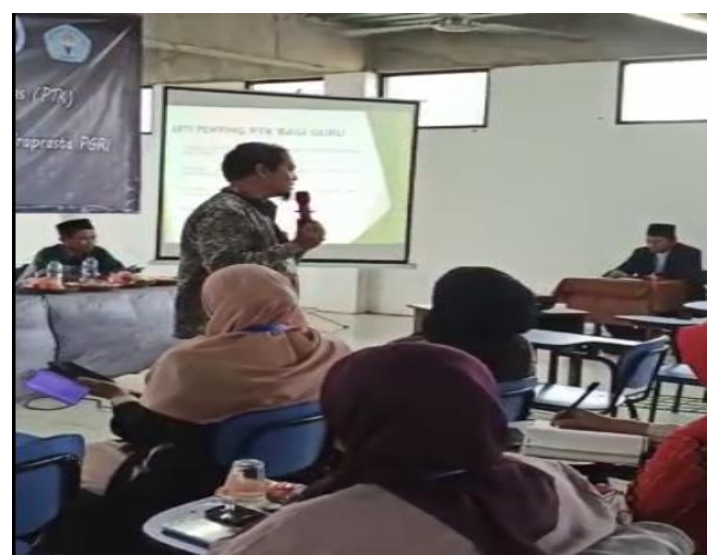

Materi selanjutnya diberikan setelah istirahat dan makan siang dengan penyampaian materi mengenai mengenai Langkah-langkah Menyusun PTK yang disampaikan oleh Fauzi Mulyatna, M.Pd hingga pukul 15.00. Pada materi ini, disampaikan mengenai langkah-langkah melakukan PTK, yang terdiri dari beberapa siklus dan masing-masing siklus terdapat tahap
Kelas (PTK) merupakan sebuah kegiatan yang dilaksanakan untuk mengamati kejadian-kejadian dalam kelas untuk memperbaiki praktek dalam pembelajaran agar lebih berkualitas dalam proses sehingga hasil belajarpun menjadi lebih baik. Lanjutnya, fokus dari PTK adalah pada kelas atau proses pembelajaran yang terjadi di kelas sendiri, bukan pada silabus, materi dll. Materi pertama disampaikan selama 45 menit hingga pukul 14.00.

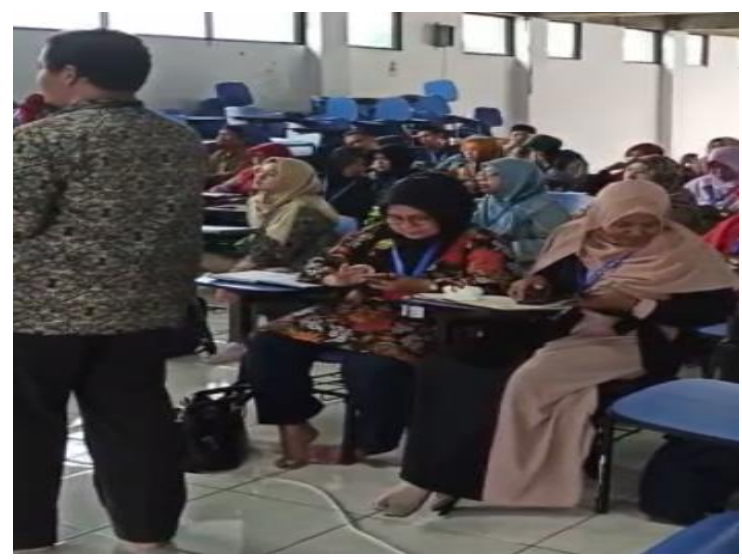

perencanaan, pelaksanaan dan pengamatan. Jumlah siklus minimal untuk PTK adalah 2 siklus. Pada materi ini, disampaikan pula contoh proposal dan laporan PTK. Pada akhir pertemuan, guru diberikan tugas berbentuk Lembar Kerja (LK) sebagai pedoman untuk merancang proposal dan laporan PTK.

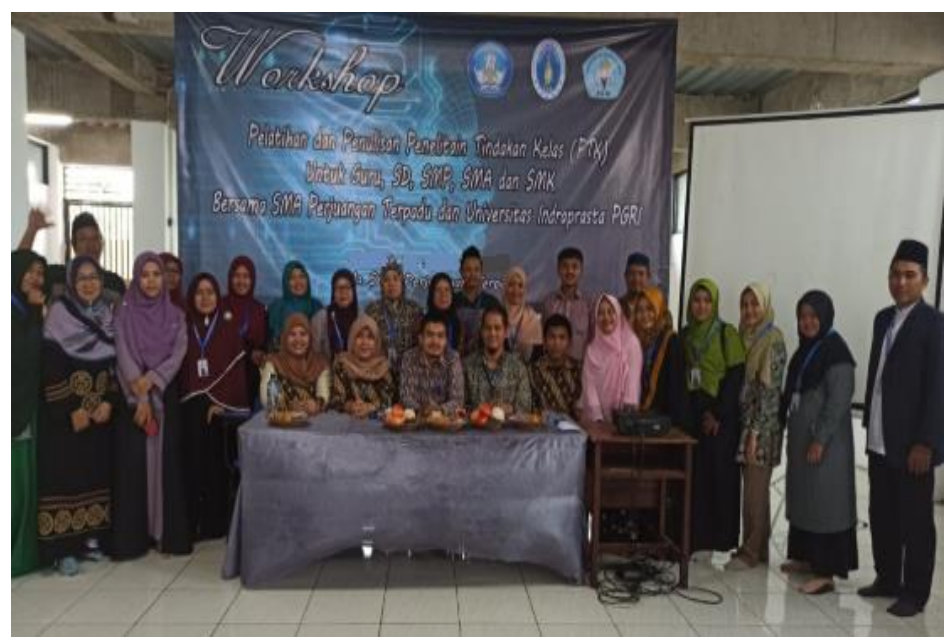

Gambar 2. Peserta Kegiatan Pelatihan PTK 
Tahap selanjutnya, adalah kegiatan monitoring dan pendampingan melalui Whatsapp dimana guru dapat menanyakan pada tim jika mengalami kendala atau kesulitan ketika menyusun proposal PTK. Namun, kegiatan pembelajaran tatap muka yang berubah menjadi pembelajaran jarak jauh akibat pandemic Covid-19 menyulitkan guru dalam melaksanakan penelitian tindakan kelas. Sehingga untuk kegiatan monitoring, peserta hanya diwajibkan membuat proposal PTK saja, tidak perlu membuat Laporan PTK.

Salah satu upaya yang dilakukan untuk meningkatkan kinerja maupun keprofesionalismean guru melalui berbagai pelatihan dan pembinaan, seperti yang dilakukan oleh tim pengabdian masyarakat yaitu PKM Penelitian Tindakan Kelas di SMA Perjuangan Terpadu Depok. Adapun pelatihan yang diberikan meliputi materi: PTK sebagai Pengembangan Profesi Guru dan Langkah-langkah Menyusun PTK.

Penelitian Tindakan Kelas (PTK) merupakan sebuah kegiatan yang dilaksanakan untuk mengamati kejadiankejadian dalam kelas untuk memperbaiki praktek dalam pembelajaran agar lebih berkualitas dalam proses sehingga hasil belajarpun menjadi lebih baik. Menurut (Somatanaya et al., 2017) Penelitian Tindakan Kelas atau dalam bahasa Inggris dikenal dengan classroom action research sejak lama berkembang di negara-negara maju seperti Inggris. Australia dan Amerika . Ahli-ahli pendidikan di negara tersebut menaruh perhatian yang cukup besar terhadap PTK. Mengapa demikian? Karena jenis penelitian ini mampu menawarkan cara dan prosedur baru untuk memperbaiki dan meningkatkan profesionalisme dalam proses belajar mengajar di kelas dengan melihat indikator keberhasilan proses pembelajaran.

Pada saat pemberian materi atau tahap pelaksanaan, sangat terlihat bahwa guru semangat dan antusias untuk melakukan PTK di kelas nya masing-masing. Pada guru sering menanyakan bagaimana cara yang mudah untuk melaksakanan penelitian dalam kondisi sedang melaksanakan proses pembelajaran. Guru sudah siap untuk merancang penelitian seperti apa yang akan mereka lakukan. Namun, akibat diberlakukannya Pembelajaran Jarak Jauh karena pandemic Covid-19 yang terjadi, sehingga pelaksaaan Penelitian Tindakan Kelas sulit dilaksanakan oleh guru. Sedangkan dalam melaksanakan PTK, situasinya akan kondusif jika memang dilaksanakan pada saat pembelajaran di kelas.

Adapun menurut (Mulia \& Suwarno, 2016) PTK merupakan penelitian tindakan yang dilakukan oleh guru sekaligus sebagai peneliti di kelasnya atau bersama-sama dengan orang lain (kolaborasi) dengan jalan merancang, melaksanakan, dan merefleksikan tindakan secara kolaboratif dan partisipatif yang bertujuan untuk memperbaiki atau meningkatkan kualitas proses pembelajaran di kelasnya melalui suatu tindakan tertentu dalam suatu siklus. Dari pendapat tersebut jelas bahwa, pelaksanaan PTK akan lebih efektif jika dilakukan secara langsung di kelas. Selain itu, dalam Penelitian Tindakan Kelas, seorang peneliti wajib menggunakan minimal dua siklus, dimana setiap siklus terdiri dari empat kegiatan. Adapun empat kegiatannya adalah perencanaan, pelaksanaan, analisis, dan refleksi. Siklus selanjutnya dilakukan perencanaan ulang, sebagai upaya untuk perbaikan pada siklus sebelumnya. Akibatnya, kegiatan pelatihan ini dapat dikatakan terlaksana dengan baik walaupun kurang maksimal karena kegiatan monitoring yang sedikit terkendala sehingga tidak dapat menghasilkan luaran yang diinginkan yaitu Laporan PTK dari masing-masing peserta. 


\section{SIMPULAN DAN SARAN}

Kegiatan pengabdian kepada masyarakat yang telah kami lakukan maka diperoleh kesimpulan bahwa, kegaiatn Pengabdian kepada Masyarakat (PkM) dengan judul pelatihan penelitian tindakan kelas dan penulisan karya tulis ilmiah di SMA Perjungan Depok. Pelaksanaan kegiatan ini dilakukan dalam tiga utama yaitu pertama dengan observasi dan menyusun rancangan kegiatan, kedua memberikan pelatihan dan pendampingan PTK, dan ketiga dengan monitoring dan evaluasi selama pelaksanaan pelatihan dan pendampingan melalui diskusi dan tanya jawab didalam ruang kelas online whatshap grup. Adapun saran pada kegaiatan PkM di SMA Perjuanan Depok, Jawa Barat. Kesadaran guru dalam memahami pentingnya membuat penelitian, menulis dan pupblikasi artikel ilmiah seharusnya menjadi suatu pedoman dan acuan guru dalam meningkatkan profesionalisme guru. Kegaiatan PkM ini merupakan sebuah awal dalam peningkatan kualitas pembelajaran di lingkungan sekolah. Peningkatan kualitas pembelajaran ini bukan hanya ditujukan pada guru saja, melainkan harus dibangun oleh semua pihak yang berada didalam dan diluar sekolah agar kualitas pembelajaran menjadi lebih baik dan berkualias.

\section{DAFTAR PUSTAKA}

Gazali, N., Cendra, R., Apriani, L., Sawira, I., \& Riau, U. I. (2019). Pelatihan dan Pendampingan Penulisan Karya Tulis Ilmiah Bagi Guru. Community Education Engagement Journal, 1(1), 8-14. https://journal.uir.ac.id/index.php/ecej/articl e/view/3669/2032

Jana, P. (2018). Pembinaan Olimpiade Matematika Kelas VA CI SD Negeri Ungaran I Yogyakarta. J-Dinamika, 2(2), 125-128. https://doi.org/10.25047/jdinamika.v2i2.527

Jayanta, I. N. L., Rati, N. W., Diputra, K. S., \& Wibawa, I. M. C. (2017). Pelatihan
Penyusunan Proposal Penelitian Tindakan Kelas Bagi Guru-Guru Sd. Jurnal Widya Laksana, 6(1), 1410-4369. blob:http://ppm.ejournal.id/e3ffc5cc-fd3541a0-adeb-659e31888b35

Marlena, N., Dwijayanti, R., Patrikha, F. D., \& Parjono, P. (2017). Pelatihan Penulisan Karya Tulis Ilmiah (Kti) Bagi Guru Sma Swasta Di Sidoarjo. Jurnal ABDI, 2(2), 45. https://doi.org/10.26740/ja.v2n2.p45-50

Mulia, D. S., \& Suwarno. (2016). PTK (Penelitian Tindakan Kelas) Dengan Pembelajaran Berbasis Kearifan Lokal Dan Penulisan Artikel Ilmiah Di SD Negeri Kalisube, Banyumas. Khazanah Pendidikan Jurnal Ilmiah Kependidikan, IX(2), 11. http://jurnalnasional.ump.ac.id/index.php/kh azanah/article/view/1062/983

Somatanaya, A. A. G., Herawati, L., \& Wahyuningsih, S. (2017). Pelatihan Penelitian Tindakan Kelas ( PTK ) Bagi Peningkatan Karier Guru-Guru Sekolah Dasar Kota Tasikmalaya. Jurnal Pengabdian Siliwangi, 3(1), 169-175. http://jurnal.unsil.ac.id/index.php/jps/article /view/218/176

Sunendiari, S., Yanti, T. S., Iswani, A., \& Suliadi. (2014). Pelatihan penelitian tindakan kelas bagi guru-guru sma di wilayah bandung dalam upaya meningkatkan kompetensi guru. Prosiding SNaPP2014 Sains, Teknologi, Dan Kesehatan, 7-14. http://proceeding.unisba.ac.id/index.php/sai ns_teknologi/article/view/530

Widayati, W., Martono, B., \& Mardiana, N. (2018). Model Diskusi pada Pelatihan Penelitian Tindakan Kelas Untuk Guru. Jurnal Ilmiah : FONEMA, 1(2), 138-151.

Wiganda, S. (2014). Pelatihan Penelitian Tindakan Kelas Bagi Guru-Guru Se-Jakarta Timur. Sarwahita, 11(1), 1. https://doi.org/10.21009/sarwahita.111.01 